\title{
PENGARUH SUNGKUP DAN JENIS MEDIA TANAM TERHADAP PERTUMBUHAN BIBIT ANGGREK Dendrobium SAAT AKLIMATISASI
}

\section{EFFECT OF HOOD APPLICATION AND TYPE OF PLANTING MEDIA TO GROWTH OF Dendrobium ORCHID SEEDLINGS DURING ACCLIMATIZATION}

\author{
Tini Sudartini ${ }^{1}$, Darul Zumani ${ }^{1}$, Della Diantini ${ }^{1}$ \\ ${ }^{1}$ Program Studi Agroteknologi Fakultas Pertanian Universitas Siliwangi \\ Fakultas Pertanian Universitas Siliwangi, Jl Siliwangi no 24, Kec. Tawang, Kota Tasikmalaya, \\ Jawa Barat Indonesia
}

Korespondensi: tinisudartini@ unsil.ac.id

\begin{abstract}
ABSTRAK
Salah satu upaya untuk meningkatkan pertumbuhan seedling anggrek invitro dalam fase aklimatisasi adalah penggunaan sungkup dan media tanam yang sesuai. Penelitian ini bertujuan: mempelajari pengaruh interaksi antara sungkup dan jenis media tanam terhadap pertumbuhan anggrek Dendrobium selama aklimatisasi Metode penelitian yang digunakan adalah metode penelitian eksperimental dengan menggunakan Rancangan Petak Terbagi. Perlakuan sungkup merupakan faktor utama yang terdiri dari 2 taraf yaitu tanpa menggunakan sungkup dan memakai sungkup serta perlakuan jenis media tanam merupakan anak petak yang terdiri dari 5 taraf yaitu pakis cacah, sabut kelapa, arang sekam, kulit pohon akasia, limbah sabut batang aren. Percobaan diulang 3 kali. Hasil penelitian menunjukkan bahwa terdapat pengaruh keterkaitan antara pemakaian sungkup dan jenis media tanam terhadap pertumbuhan anggrek selama aklimatisasi. Pemakaian sungkup dan jenis media arang sekam menghasilkan pertumbuhan bibit anggrek yang terbaik selama aklimatisasi.
\end{abstract}

Kata kunci: bibit anggrek dendrobium , aklimatisasi, sungkup, jenis media tanam

\begin{abstract}
One of the efforts to increase in vitro orchid seedlings growth in acclimatization phase are the use of hoods and appropriate planting media. The research was aimed to find out the best interaction effect between hood application and planting media types to growth of in vitro Dendrobium seedlings during acclimatization. The experiment design used was split plot design. Treatment of hood application was the main plot divided to s0 (plant without hood) and s1 (plant with hood). The treatment of planting media types was the sub plot comprises of $\mathrm{m} 1$ (fern), $\mathrm{m} 2$ (coconut fiber), $\mathrm{m} 3$ (husk charcoal), $\mathrm{m} 4$ (acacia tree bark) and $\mathrm{m} 5$ (sugar palm fiber waste) The experiment unit was replicated 3 times. The results showed that there were the interaction effects between hood application and planting media types to acclimatized Dendrobium seedling growth. The best interaction was the Dendrobium seedling planted on husk charcoal media and covered by hoods
\end{abstract}

Key words: dendrobium orchid seedling, acclimatization, cover plant 


\section{PENDAHULUAN}

Anggrek (Orchidaceae) merupakan salah satu tanaman hias yang sangat indah dan mempunyai nilai ekonomis yang tinggi. Tanaman anggrek saat ini yang paling popular diperjual belikan adalah dendrobium. Keistimewaan anggrek ini sebagai bunga potong adalah mudah ditanam, berbunga terus menerus, warna bunga bervariasi, berbatang lentur sehingga mudah dirangkai dan kesegaran bunga yang bertahan lama (Surtinah dan Mutryarny, Enny, 2013).

Peningkatan permintaan dalam negeri terhadap anggrek berjalan seiring dengan meningkatnya tingkat kesejahteraan masyarakat, pengembangan tempat wisata dan lain lain. Menurut Widyastoety, Nina dan Muchdar (2010), kendala pengembangan anggrek di Indonesia antara

lain adalah terbatasnya bibit unggul, teknologi yang digunakan masih sederhana dan kurangnya dukungan kebijakan pemerintah.

Pengembangan produksi tanaman anggrek Dendrobium sangat tergantung dengan ketersediaan bibit anggrek yang bermutu tinggi. Bibit anggrek yang berkualitas akan menghasilkan bunga dengan baik. Ciri-ciri bibit Dendrobium yang baik yaitu batang kuat, pertumbuhan pesat dan subur. Bibit anggrek yang dikembangkan menggunakan metode kultur jaringan yang telah banyak diproduksi dan dipasarkan dalam kemasan botol. Bibit yang baru dikeluarkan dari botol tersebut memerlukan fase aklimatisasi , yaitu pemindahan bibit dari lingkungan aseptik dalam botol ke lingkungan non aseptik. Menurut Adipura (2007), disamping kemungkinan tanaman sangat sensitif terhadap serangan hama dan penyakit, tanaman masih memiliki aktifitas autotrofik yang masih rendah, sulit mensintesa senyawa organik dari unsur hara anorganik
Dalam pelaksanaan di lapangan pada saat proses aklimatisasi masih menemukan beberapa kendala salah satunya terjadinya proses transpirasi (penguapan) yang tinggi, sehingga menyebabkan berkurangnya atau hilangnya kandungan air dalam jaringan tanaman. Salah satu metode yang dapat digunakan untuk mempertahankan kelembaban dalam media ialah metode sungkup. Penyungkupam dapat menekan proses transpirasi sehingga kelembaban akan terpelihara. Beberapa praktisi anggrek telah mempraktekan metode sungkup pada aklimatisasi anggrek, secara kasat mata hasil bibit anggrek dengan metode sungkup dapat dikatakan berhasil karena dilihat dari persentasi hidup mencapai $98 \%$ dan menghemat waktu untuk melakukan penyiraman. Menurut Junaedy (2017), pemberian sungkup pada stek tanaman nusa indah memberikan pengaruh terbaik terhadap parameter luas daun.

Media tumbuh bagi bibit merupakan lingkungan baru dalam proses aklimatisasi. Media tumbuh yang baik bagi anggrek harus memenuhi beberapa persyaratan, antara lain tidak cepat melapuk dan terdekomposisi, tidak menjadi sumber penyakit bagi tanaman, mempunyai aerasi dan drainase yang baik serta lancar, mampu mengikat air dan zat-zat hara secara optimal, dapat mempertahankan kelembaban di sekitar akar. Pertumbuhan anggrek membutuhkan $\mathrm{pH}$ media antara 5 sampai dengan 6, ramah lingkungan serta mudah diperoleh dan relatif murah harganya (Ginting, 2008) dalam Wardani, Setiado dan Ilyas, (2013).

Media pakis merupakan media yang umum digunakan sebagai media tanam anggrek. Media tanam pakis mempunyai daya mengikat air, aerasi dan drainase yang baik, lapuk secara perlahan-lahan, namun mengandung unsur hara yang (Febrizawati, dkk, 2014). Namun permintaan pakis yang semakin banyak akan meningkatkan harga jual dan pengadaan pakis menjadi terbatas. 
Salah satu usaha untuk mengatasi hal tersebut adalah dengan mencari alternatif media tanam yang baik digunakan untuk pertumbuhan anggrek (Andalasari, dkk, 2014). Media alternatif yang digunakan dapat berupa limbah yang berasal dari industri pertanian seperti sekam bakar, sabut kelapa, kulit pohon akasia dan limbah sagu

Sabut kelapa yang digunakan merupakan limbah hasil sortasi sabut kelapa untuk ekspor. Sabut kelapa sebagai media tanam memiliki kemampuan yang cukup menyimpan air dan mengandung zat hara organik namun pada media tanam sabut kelapa sering terjadi serangan hama dan penyakit pada bagian akar tanaman. Pecahan batu bata sedikit menyerap air, mudah melepas air, drainase dan aerasi baik serta miskin unsur hara (Febrizawati, dkk., 2014). Arang sekan merupakan limbah dari penggilingan padi, ketersediaan sekam mudah didapat dan harganya murah, selain itu arang sekam merupakan media steril karena telah melewati proses pembakaran. Media kulit kayu memiliki drainase dan aerasi yang baik, sulit lapuk karena mengandung senyawa selulosa, lignin dan hemiselulosa (Susanto, 2018). Kulit Kulit kayu merupakan limbah pabrik pemotongan kayu, keberadaanya mudah didapat dan harganya murah bahkan dibuang begitu saja, sehingga dapat menjadi peluang sebagai media alternatif anggrek. Media limbah aren merupakan limbah dari pabrik pembuatan pati aren.

Royani dan Erma (2015) menyatakan bahwa penggunaan media limbah sagu segar dapat digunakan sebagai media tanam anggrek. Anggrek yang ditanam pada media limbah sagu segar lebih optimal pertumbuhannya dibanding dengan anggrek yang ditanam pada media limbah sagu hitam.

Pada media yang memiliki daya serap yang tinggi dan daya simpan air yang tinggi maka kelembaban media akan terjaga, sebaliknya jika media memiliki daya serap yang tinggi namun memiliki tingkat menyimpan air yang rendah akan mudah kehilangan air, sehingga penggunaan sungkup diharapkan dapat mengendalikan kelembaban dalam media tanam anggrek saat aklimatisasi.

Berdasarkan uraian diatas maka penulis meneliti pengaruh sungkup dan jenis media tanam terhadap pertumbuhan bibit anggrek dendrobium hibrida saat aklimatisasi

\section{Identifikasi Masalah.}

Berdasarkan uraian pada latar belakang di atas maka masalah yang dapat diidentifikasi pada penelitian ini ialah : Apakah ada pengaruh interaksi antara sungkup dengan jenis media tanam terhadap pertumbuhan bibit anggrek dendrobium hibrida saat aklimatisasi ?

\section{Tujuan Penelitian.}

Penelitian ini dilaksanakan dengan tujuan untuk mempelajari pengaruh interaksi antara sungkup dan jenis media tanam terhadap pertumbuhan anggrek Dendrobium saat aklimatisasi.

\section{Kegunaan Penelitian}

Penelitian ini diharapkan berguna sebagai informasi mengenai pengaruh sungkup dan jenis media tanam dalam proses aklimatisasi anggrek di dataran menengah, sehingga didapatkan seedling yang berkualitas baik

\section{BAHAN DAN METODE} Tempat dan waktu penelitian.

Penelitian dilaksanakan di screen house UPT Balai Benih Hortikultura dan Kultur Jaringan, Kp. Cihaur, Desa Tobongjaya Kecamatan Cipatujah, Kabupaten Tasikmalaya dimulai tanggal 1 April sampai dengan17 Juni 2019, pada ketinggian tempat $241 \mathrm{~m} \mathrm{dpl}$. 


\section{Bahan dan Alat Percobaan}

Bahan percobaan yang digunakan adalah : bibit anggrek Dendrobium hybrid silangan Dendrobium sylvanum dan Dendrobium devosianum hasil kultur jaringan dari bibit dalam botol

Alat percobaan yang akan digunakan adalah : naungan plastik/paranet, rak pot, pot tanah liat diameter $15 \mathrm{~cm}$, pot plastik diameter $7 \mathrm{~cm}$, solder, kawat, gelas ukur, timbangan, mistar, label perlakuan, pinset, pengait, alat tulis, kamera, higrometer termometer dan lux meter.

\section{Analisis Data}

Penelitian ini menggunakan metode eksperimen dengan Rancangan Petak Terbagi yang terdiri dari dua faktor perlakuan yaitu: faktor perlakuan petak utama : sungkup yang terdiri dari 2 taraf: $\mathrm{S}_{\mathrm{o}}=$ tanpa sungkup; $\mathrm{S}_{1}=$ diberi sungkup. Faktor kedua anak petak: jenis media tanam yang terdiri dari 5 taraf: $\mathrm{m}_{1}=$ potongan akar pakis; $\mathrm{m}_{2}=$ sabut kelapa; $\mathrm{m}_{3}=$ arang sekam; $\mathrm{m}_{4}=$ kulit pohon akasia ; m5 = limbah sabut batang aren . Percobaan terdiri dari 10 kombinasi perlakuan antara sungkup dan media tanam, yaitu : $\mathrm{s}_{\mathrm{o}} \mathrm{m}_{1}, \mathrm{~s}_{\mathrm{o}} \mathrm{m}_{2}$, $\mathrm{s}_{\mathrm{o}} \mathrm{m}_{3}, \mathrm{~s}_{\mathrm{o}} \mathrm{m}_{4}, \mathrm{~s}_{0} \mathrm{~m}_{5} ; \mathrm{s}_{1} \mathrm{~m}_{1}, \mathrm{~s}_{1} \mathrm{im}_{2}, \mathrm{~s}_{1} \mathrm{~m}_{3}, \mathrm{~s}_{1} \mathrm{~m}_{4}, \mathrm{~s}_{1} \mathrm{~m}_{5}$. Setiap kombinasi perlakuan diulang sebanyak 3 kali, sehingga keseluruhan terdapat 30 plot percobaan. Setiap plot percobaan terdiri dari 10 planlet, sehingga dibutuhkan 300 planlet anggrek. Pengambilan sampel dilakukan dengan metode zigzag, jumlah sampel tanaman per plot 5 tanaman. Analisis data hasil pengamatan diuji menggunakan uji $\mathrm{F}$, yang disajikan pada daftar sidik ragam. Kaidah penganbilan keputusan : $F$ hitung $\leq \mathrm{f}$ tabel : perlakuan berbeda tidak nyata, tidak dipengaruhi; hipotesis nol $\left(\mathrm{H}_{0}\right)$ diterima. Fhitung $\geq \mathrm{f}$ tabel maka perlakuan berbeda nyata, dipengaruhi : hipotesa satu $\left(\mathrm{H}_{1}\right)$ diterima. Apabila dalam $\mathrm{f}$ hitung menunjukkan perbedaan yang nyata, maka dilakukan Uji lanjutan Jarak berganda Duncan pada taraf 5\% .

\section{Parameter Penelitian.}

Parameter penunjang : data suhu dan kelembaban, intensitas cahaya matahari di screen house selama percobaan. Organisme penggangu tanaman dan persentasi hidup.

Pengamatan utama terdiri dari parameter : Pertambahan tinggi tanaman, jumlah daun, luas daun, pertambahan jumlah akar, pertambahan panjang akar, pertambahan bobot brangkasan segar

Pengamatan utama dimulai umur 15 hari sampai umur 75 hari setelah tanam (hst). Pengamatan dilakukan terhadap 5 tanaman sampel pada setiap perlakuan.

\section{HASIL DAN PEMBAHASAN}

Suhu udara rata-rata yaitu $26,2^{\circ} \mathrm{C}$. Suhu udara minimun $21^{\circ} \mathrm{C}$ dan suhu udara maksimum $34,8{ }^{\circ} \mathrm{C}$. Suhu pagi hari berkisar antara $21{ }^{\circ} \mathrm{C}$ sampai $25,4{ }^{\circ} \mathrm{C}$, siang hari berkisar dari suhu $22,1^{\circ} \mathrm{C}$ sampai dengan 26,1 ${ }^{\circ} \mathrm{C}$. Berdasarkan data tersebut menunjukkan bahwa suhu tempat aklimatisasi udara cukup optimum. Menurut Susanto (2018), untuk pertumbuhan anggrek dendrobium suhu udara rata-rata $25^{\circ} \mathrm{C}$ sampai $27^{\circ} \mathrm{C}$. suhu udara minimum $21^{\circ} \mathrm{C}$ sampai $23^{\circ} \mathrm{C}$ dan maksimum $31^{\circ} \mathrm{C}$ sampai $34^{\circ} \mathrm{C}$. Suhu siang hari sebaiknya $27^{\circ} \mathrm{C}$ sampai $32^{\circ} \mathrm{C}$, sedangkan pada malam hari $21^{\circ} \mathrm{C}$ sampai $24^{\circ} \mathrm{C}$.

Kelembaban udara rata-rata di screen house yaitu $83,15 \%$. Kelembaban udara minimun $50 \%$ dan kelembaban udara maksimum $99 \%$. Kelembaban pada pagi hari berkisar antara $84 \%$ sampai $99 \%$, siang hari berkisar antara $50 \%$ sampai $86 \%$ dan kelembaban pada malam hari berkisar antara 73\% sampai 99\%. Kelembaban lingkungan aklimatisasi dalam kondisi optimum. 
Menurut Susanto (2018), kelembaban yang dibutuhkan anggrek Dendrobium berkisar 60 sampai $80 \%$

\section{Intensitas cahaya matahari}

Intensitas cahaya matahari dalam screenhouse yang menggunakan kerapatan net $65 \%$ pada siang hari berkisar antara 52,9 sampai 2164,6 fc. Fakta tersebut sesuai dengan intensitas cahaya yang diingikan oleh bibit anggrek. Menurut Susanto (2018), penyinaran pada tanaman anggrek yang berkisar antara 1500-3000 fc.

\section{Organisme pengganggu tanaman.}

Selama pengamatan tidak ada hama yang menyerang tanaman, sedangkan penyakit yang menyerang bibit anggrek selama pengamatan yaitu busuk pangkal batang dan gulma yang tumbuh pada media pembibitan anggrek adalah lumut yang berada pada media dan menempel disekitar pot. Penyakit busuk pangkal batang menunjukkan gejala bagian pangkal mengkerut berwarna hitam, kemudian terputus bagian batang dan akarnya. Penyakit ini menyerang pada tanaman bibit tanpa sungkup.

\section{Persentasi hidup.}

Persentasi hidup tanaman anggrek dendrobium hibrida saat aklimatisasi pada perlakuan tanpa sungkup berkisar antara 93\% sampai $100 \%$. Pada perlakuan sungkup persentasi hidup bibit anggrek 100\%.

\section{Pengamatan Utama}

Hasil analis statistik menunjukkan terdapat pengaruh interaksi antara sungkup dan jenis media tanam terhadap parameter jumlah daun umur 45, luas daun umur $75 \mathrm{hst}$ dan bobot brangkasan segar. Pengaruh sungkup secara mandiri berpengaruh tidak nyata terhadap semua parameter pengamatan, sedangkan jenis media tanam secara mandiri berpengaruh nyata terhadap parameter pengamatan pertambahan tinggi tanaman umur 45 hst dan 75 hst, jumlah daun umur 30 dan 60 hst, pertambahan jumlah akar pertanaman umur 75 hst dan pertambahan panjang akar umur 75 hst. Menurut Zulkarnain (2009) dalam Sukmadijaya, Dinarti dan Isnaini (2013) faktor-faktor yang mempengaruhi pertumbuhan planlet selama tahap aklimatisasi adalah media tanam, intensitas cahaya, kelembaban dan suhu ruang.

\section{Pertambahan tinggi tanaman.}

Pengaruh sungkup berbeda tidak nyata terhadap pertambahan tinggi tanaman pada semua umur tanaman, sedangkan pengaruh jenis media tanam berbeda nyata terhadap pertambahan tinggi tanaman umur 45 hst dan 75 hst.

Tabel analisis statistik pengaruh sungkup dan jenis media tanam terhadap parameter pengamatan pertambahan tinggi tanaman dapat dilihat pada Tabel 4, sebagai berikut.

Pengaruh sungkup berbeda tidak nyata terhadap pertambahan tinggi tanaman pada semua umur pengamatan. Hal ini diduga meskipun tanpa sungkup proses evapotranspirasi masih dapat diimbangi absoprsi air oleh akar serta kelembaban di dalam screen house mampu mengendalikan lajunya. Faktor lingkungan seperti suhu, kelembaban dan intensitas cahaya telah memenuhi persyaratan tumbuh bibit anggrek dendrobium selama tahap aklimatisasi. Fungsi media tanam selain sebagai tempat tumbuh tanaman juga dapat memenuhi kebutuhan unsur hara dan air yang dibutuhkan oleh tanaman. Pada umur 30 hst dan 60 hst, semua jenis media tanam berbeda tidak nyata. 
Tabel 4. Analisis statistik pengaruh sungkup dan jenis media tanam pertambahan tinggi tanaman per tanaman $(\mathrm{cm})$ pada umur 30, 45, 60 dan $75 \mathrm{hst}$

\begin{tabular}{|c|c|c|c|c|}
\hline \multirow{2}{*}{$\begin{array}{c}\text { Umur } \\
\text { tanaman }\end{array}$} & \multirow{2}{*}{ Anak Petak } & \multicolumn{2}{|c|}{ Petak Utama } & \multirow[b]{2}{*}{ Rata-rata } \\
\hline & & $\begin{array}{c}\text { Tanpa } \\
\text { sungkup }\end{array}$ & Sungkup & \\
\hline \multirow{7}{*}{$30 \mathrm{HST}$} & Pakis & 0,86 & 0,84 & $0,85 \mathrm{a}$ \\
\hline & Sabut kelapa & 0,87 & 0,93 & $0,90 \mathrm{a}$ \\
\hline & Arang sekam & 0,86 & 0,89 & $0,87 \mathrm{a}$ \\
\hline & Kulit pohon akasia & 0,78 & 0,86 & $0,82 \mathrm{a}$ \\
\hline & Limbah sabut batang aren & 0,81 & 0,79 & $0,80 \mathrm{a}$ \\
\hline & Rata-rata & 0,84 & 0,86 & \\
\hline & & $\mathrm{A}$ & $\mathrm{A}$ & \\
\hline \multirow[t]{7}{*}{$45 \mathrm{HST}$} & Pakis & 0,07 & 0,16 & $0,11 \mathrm{~b}$ \\
\hline & Sabut kelapa & 0,12 & 0,14 & $0,13 \mathrm{~b}$ \\
\hline & Arang sekam & 0,08 & 0,15 & $0,11 \mathrm{~b}$ \\
\hline & Kulit pohon akasia & 0,06 & 0,04 & $0,05 \mathrm{a}$ \\
\hline & Limbah sabut batang aren & 0,07 & 0,08 & $0,08 \mathrm{ab}$ \\
\hline & Rata-rata & 0,08 & 0,11 & \\
\hline & & $\mathrm{A}$ & $\mathrm{A}$ & \\
\hline \multirow[t]{7}{*}{$60 \mathrm{HST}$} & Pakis & 0,74 & 0,74 & $0,74 \mathrm{a}$ \\
\hline & Sabut kelapa & 0,78 & 0,75 & $0,77 \mathrm{a}$ \\
\hline & Arang sekam & 0,77 & 0,77 & $0,77 \mathrm{a}$ \\
\hline & Kulit pohon akasia & 0,74 & 0,76 & $0,75 \mathrm{a}$ \\
\hline & Limbah sabut batang aren & 0,76 & 0,78 & $0,77 \mathrm{a}$ \\
\hline & Rata-rata & 0,76 & 0,76 & \\
\hline & & A & A & \\
\hline \multirow[t]{7}{*}{75 HST } & Pakis & 0,09 & 0,33 & $0,21 \mathrm{ab}$ \\
\hline & Sabut kelapa & 0,19 & 0,26 & $0,22 \mathrm{ab}$ \\
\hline & Arang sekam & 0,41 & 0,28 & $0,34 \mathrm{~b}$ \\
\hline & Kulit pohon akasia & 0,12 & 0,19 & $0,15 \mathrm{a}$ \\
\hline & Limbah sabut batang aren & 0,18 & 0,08 & $0,13 \mathrm{a}$ \\
\hline & Rata-rata & 0,20 & 0,23 & \\
\hline & & A & A & \\
\hline
\end{tabular}

Keterangan:Angka yang diikuti oleh huruf kecil yang sama arah vertikal dan huruf besar sama arah horizontal menunjukkan pengaruh tidak berbeda nyata menurut uji jarak berganda Duncan pada taraf nyata 5\%.

Hal ini diduga karena semua jenis media tanam masih cukup menyediakan unsur hara yang berasal dari larutan nutrisi yang selalu ditambahkan setiap 7 hari. Pengamatan pada umur 45 hst menunjukkan bahwa jenis media tanam berbeda nyata terhadap pertambahan tinggi tanaman. Media pakis berbeda tidak nyata dengan media sabut kelapa dan arang sekam. Media kulit pohon akasia berbeda nyata dengan media pakis, sabut kelapa dan arang sekam. Media sabut aren berbeda tidak nyata dengan seluruh perlakuan media. Pertambahan tinggi tanaman yang paling sedikit terdapat pada media kulit pohon akasia. Hal ini disebabkan karena kulit pohon akasia memiliki tekstur yang kasar dan pori-pori yang besar sehingga media sulit menyerap nutrisi yang tersedia dari larutan nutrisi. 
Pada umur 75 hst menunjukkan bahwa jenis media tanam berbeda nyata terhadap pertambahan tinggi tanaman, sedangkan pengaruh sungkup berbeda tidak nyata. pertambahan tinggi Pertambahan tinggi yang lebih baik yaitu pada jenis media arang sekam. Hal ini disebabkan karena media arang sekam merupakan media yang memiliki karakteristik yang ringan, kasar sehingga sirkulasi udara tinggi, kemampuan menahan air tinggi. Menurut Andalasari, dkk (2014), penggunaan media tanam arang, serbuk gergaji + sekam, kulit pohon akasia, kulit pohon kelapa dapat digunakan sebagai media tanam anggek sama seperti media pakis.

\section{Jumlah daun.}

Pengaruh sungkup tidak berbeda nyata terhadap jumlah daun pada semua umur pengamatan. Hal ini disebabkan, meskipun pada perlakuan tanpa sungkup, iklim mikro yang terdapat di tempat aklimatisasi, sangat terkendali karena beradaa dalam screen house di bawah paranet. Kelembaban, suhu dan intensitas cahaya yang terkendali menyebabkan kehilangan air karena proses evapotraspirasi masih diimbangi oleh proses absopsi.

Pengaruh jenis media tanam berbeda tidak nyata terhadap jumlah daun pada umur $30 \mathrm{hst}$ dan 60 hst, sedangkan pada umur 45 hat dan 75 hst jumlah daun berbeda nyata pada berbagai jenis media tanam (Tabel 5).

Tabel 5. Analisis statistik pengaruh sungkup dan jenis media tanam terhadap jumlah daun per tanaman (helai) pada umur 15 hst dan 30 hst

\begin{tabular}{clccc}
\hline \multirow{2}{*}{$\begin{array}{c}\text { Umur } \\
\text { tanaman }\end{array}$} & \multicolumn{1}{c}{ Anak Petak } & \multicolumn{2}{c}{ Petak Utama } & Tanpa \\
& & Sungkup & Rata-rata \\
& sungkup & & \\
\hline \multirow{3}{*}{$15 \mathrm{HST}$} & 3,40 & 3,06 & $3,23 \mathrm{a}$ \\
& Pakis & 3,67 & 3,47 & $3,57 \mathrm{a}$ \\
& Sabut kelapa & 3,33 & 2,93 & $3,13 \mathrm{a}$ \\
& Krang sekam & 3,67 & 3,13 & $3,40 \mathrm{a}$ \\
& Kulit pohon akasia & 3,33 & 3,40 & $3,37 \mathrm{a}$ \\
& Limbah sabut batang aren & 3,48 & 3,20 & \\
& Rata-rata & $\mathrm{A}$ & $\mathrm{A}$ & \\
\hline \multirow{3}{*}{$30 \mathrm{HST}$} & 3,46 & 3,33 & $3,40 \mathrm{ab}$ \\
& Pakis & 3,60 & 3,66 & $3,63 \mathrm{~b}$ \\
& Sabut kelapa & 3,13 & 3,00 & $3,06 \mathrm{a}$ \\
& Arang sekam & 3,13 & 3,26 & $3,20 \mathrm{a}$ \\
& Kulit pohon akasia & 3,20 & 3,13 & $3,16 \mathrm{a}$ \\
& Limbah sabut batang aren & 9,92 & 9,84 & \\
& Rata-rata & $\mathrm{A}$ & $\mathrm{A}$ & \\
\hline
\end{tabular}

Keterangan : Angka yang diikuti oleh huruf kecil yang sama arah vertikal dan huruf besar sama arah horizontal menunjukkan pengaruh tidak berbeda nyata menurut uji jarak berganda Duncan pada taraf nyata 5\%.

Media pakis berbeda tidak nyata dengan media sabut kelapa, arang sekam, kulit pohon akasia dan sabut aren. Media sabut kelapa memberikan pengaruh yang lebih baik terhadap parameter jumlah daun. Hal ini diduga karena sabut kelapa mampu menyerap dan menyimpan air, dan memiliki kandungan unsur hara yang dibutuhkan untuk pertumbuhan bibit anggrek yang dapat mendorong pertumbuhan daun. Menurut Astutik (2006), bahwa penggunaan sabut kelapa sebagai media tanam anggrek 
dendrobium pada saat aklimatisasi memberikan pengaruh terbaik terhadap parameter pertambahan jumlah daun.

Pada umur 45 hst, terjadi pengaruh interaksi antara sungkup dan jenis media tanam terhadap jumlah daun. Pada perlakuan tanpa sungkup dan pemakain sungkup jenis media tanam berbeda tidak nyata.

Pengaruh sungkup pada media pakis, sabut kelapa, arang sekam dan kulit pohon akasia berbeda tidak nyata, namun berbeda nyata pada limbah sabut aren . Pada perlakuan tanpa sungkup dengan jenis media tanam limbah sabut batang aren menunjukkan jumlah daun yang lebih banyak. Hal ini disebabkan media sabut aren dari pabrik tepung kanji yang tidak dipisahkan dari serbuknya, menyebabkan media mampu menyerap dan menyimpan air lebih lama, sehingga meskipun tanpa menggunakan sungkup dapat mempertahankan kelembaban. Limbah sabut aren memiliki kandungan unsur hara yang dibutuhkan dalam pertumbuhan tanaman, tekstur yang porous, aerasi dan drainase baik dapat menyimpan air lebih lama sehingga tanaman tumbuh lebih baik meskipun tanpa sungkup.

Menurut Royani dan Prihastanti (2015), limbah sagu segar mengandung unsur hara makro nitrogen $(\mathrm{N})$ sebesar $1,44 \%$, fosfor $(\mathrm{P})$ sebesar 0,46\% dan kalium (K) sebesar 2,33\% yang digunakan sebagai nutrisi pertumbuhan anggrek. Selain itu sagu segar memiliki bentuk serat yang panjang dan susunannya tidak terlalu rapat sehingga memiliki pori (Tabel 6)

Tabel 6. Analisis statistik pengaruh sungkup dan jenis media tanam terhadap jumlah daun per tanaman (helai) pada umur 45 hst.

\begin{tabular}{lcc}
\hline \multirow{1}{*}{ Anak Petak } & \multicolumn{2}{c}{ Petak Utama } \\
& Tanpa sungkup & Sungkup \\
\hline Pakis & $3,46 \mathrm{a}$ & $3,80 \mathrm{a}$ \\
Sabut kelapa & $\mathrm{A}$ & $\mathrm{A}$ \\
& $3,53 \mathrm{a}$ & $4,06 \mathrm{a}$ \\
Arang sekam & $\mathrm{A}$ & $\mathrm{A}$ \\
& $3,13 \mathrm{a}$ & $3,60 \mathrm{a}$ \\
Kulit pohon akasia & $\mathrm{A}$ & $\mathrm{A}$ \\
& $2,86 \mathrm{a}$ & $3,13 \mathrm{a}$ \\
Limbah sabut batang aren & $\mathrm{A}$ & $\mathrm{A}$ \\
& $3,73 \mathrm{a}$ & $2,60 \mathrm{a}$ \\
\hline
\end{tabular}

Keterangan :Angka yang diikuti oleh huruf kecil yang sama arah vertikal dan huruf besar sama arah horizontal menunjukkan pengaruh tidak berbeda nyata menurut uji jarak berganda Duncan pada taraf nyata 5\%.

Pada Tabel 7 dapat dilihat tidak terdapat pengaruh interaksi sungkup dan jenis media tanam terhadap jumlah daun pada umur 60 hst dan 75 hst. Pengaruh jenis media tanam berbeda nyata terhadap jumlah daun pada umur 60 hst, sedangkan pada umur 75 hst jumlah daun berbeda tidak nyata. Media pakis berbeda tidak nyata dengan media sabut kelapa, arang sekam dan limbah sabut batang aren. Jumlah daun lebih banyak terdapat pada jenis media sabut kelapa.

Jumlah daun yang paling sedikit terdapat pada jenis media tanam kulit pohon akasia. Hal ini diduga karena kulit pohon akasia memiliki kandungan senyawa selulosa, lignin dan hemiselulosa yang menyebabkan media 
sulit lapuk karena media tidak dilakukan proses pengomposan dulu. John dan Bowyer (1986) dalam Andalasri. dkk, (2014) menyatakan bahwa kulit batang akasia mengandung lignin dan polisakarida, akan tetapi jika dikomposkan bahan ini akan melapuk dan terurai menjadi bahan yang lebih sederhana dan dapat menambah unsur hara.

Tabel 7. Analisis statistik pengaruh sungkup dan jenis media tanam terhada jumlah daun per tanaman (helai) pada umur 60 HST dan 75 HST

\begin{tabular}{clccc}
\hline \multirow{2}{*}{$\begin{array}{c}\text { Umur } \\
\text { tanaman }\end{array}$} & \multicolumn{1}{c}{ Anak Petak } & \multicolumn{2}{c}{ Petak Utama } & \\
\cline { 3 - 4 } & & $\begin{array}{c}\text { Tanpa } \\
\text { sungkup }\end{array}$ & Sungkup & \\
\hline \multirow{5}{*}{$60 \mathrm{HST}$} & Pakis & 3,33 & 3,80 & $3,56 \mathrm{bc}$ \\
& Sabut kelapa & 3,73 & 4,26 & $4,00 \mathrm{c}$ \\
& Arang sekam & 3,06 & 3,66 & $3,36 \mathrm{~b}$ \\
& Kulit pohon akasia & 2,46 & 3,06 & $2,76 \mathrm{a}$ \\
& Limbah sabut batang aren & 3,46 & 2,93 & $3,20 \mathrm{~b}$ \\
& Rata-rata & 3,21 & 3,54 & \\
& & $\mathrm{~A}$ & $\mathrm{~A}$ & \\
\hline \multirow{5}{*}{$75 \mathrm{HST}$} & Pakis & 3,53 & 3,67 & $3,60 \mathrm{a}$ \\
& Sabut kelapa & 3,27 & 4,80 & $4,04 \mathrm{a}$ \\
& Arang sekam & 3,20 & 4,13 & $3,67 \mathrm{a}$ \\
& Kulit pohon akasia & 2,67 & 3,33 & $3,00 \mathrm{a}$ \\
& Limbah sabut batang aren & 3,67 & 3,67 & $3,67 \mathrm{a}$ \\
& Rata-rata & 3,27 & 3,92 & \\
\hline
\end{tabular}

Keterangan : Angka yang diikuti oleh huruf kecil yang sama arah vertikal dan huruf besar sama arah horizontal menunjukkan pengaruh tidak berbeda nyata menurut uji jarak berganda Duncan pada taraf nyata 5\%

Tabel 8 menyajikan hasil analisis luas daun. Tabel tersebut menunjukkan bahwa terjadi pengaruh interaksi antara sungkup dan jenis media tanam terhadap luas daun. Perlakuan sungkup pada perlakuan media pakis tidak berbeda dengan perlakuan media sabut kelapa, arang sekam dan sabut aren. Media sabut kelapa tidak berbeda dengan perlakuan media pakis, kulit pohon akasia dan sabut aren. media arang sekam tidak berbeda nyata dengan media pakis, namun berbeda dengan perlakuan media sabut kelapa, kulit pohon akasia dan sabut aren. Namun demikian perlakuan tanpa sungkup

Menurut Purwono (2005) dalam Junaedy (2017), bahwa naungan (sungkup) memberikan efek yang nyata terhadap luas daun. Daun yang berada pada perlakuan tidak berbeda pada semua jenis media tanam. Menurut Andalasari, dkk (2014), Penggunaan media tanam arang, serbuk gergaji + sekam, kulit pohon akasia, kulit pohon kelapa dapat digunakan sebagai media tanam anggek sama seperti media pakis. Daun paling luas dihasilkan dari interaksi jenis media tanam sekam dengan pemakaian sungkup. Hal ini disebabkan walaupun arang sekam memiliki tekstur porous, tetap dapat mempertahankan cairan nutrisi dengan baik akibat penggunaan sungkup. Sungkup dapat mencegah terjadinya evaporasi cairan nutrisi dari media arang sekam.

Sungkup mempunyai permukaan yang lebih luas dibandingkan daun yang berada pada perlakuan tanpa sungkup. 
Tabel 8. Analisis statistik pengaruh sungkup dan jenis media tanam terhadap luas daun per tanaman $\left(\mathrm{cm}^{2}\right)$ umur 75 HST

Anak Petak

\section{Petak Utama}

\begin{tabular}{lcc}
\multicolumn{1}{c}{ Anak Petak } & Tanpa sungkup & Sungkup \\
\hline Pakis & $4,71 \mathrm{a}$ & $5,62 \mathrm{bc}$ \\
& $\mathrm{A}$ & $\mathrm{A}$ \\
Sabut kelapa & $4,01 \mathrm{a}$ & $3,98 \mathrm{ab}$ \\
& $\mathrm{A}$ & $\mathrm{A}$ \\
Arang sekam & $4,43 \mathrm{a}$ & $7,44 \mathrm{c}$ \\
& $\mathrm{A}$ & $\mathrm{B}$ \\
Kulit pohon akasia & $2,37 \mathrm{a}$ & $2,19 \mathrm{a}$ \\
& $\mathrm{A}$ & $\mathrm{A}$ \\
Limbah sabut batang aren & $3,25 \mathrm{a}$ & $3,40 \mathrm{ab}$ \\
& $\mathrm{A}$ & $\mathrm{A}$ \\
\hline
\end{tabular}

Keterangan : angka yang diikuti oleh huruf kecil yang sama arah vertikal dan huruf besar sama arah horizontal menunjukkan pengaruh tidak berbeda nyata menurut uji jarak berganda Duncan pada taraf nyata $5 \%$.

\section{Pertambahan jumlah akar.}

Tabel 9 menunjukkan jumlah akar berbeda nyata pada jenis media tanam, sedangkan pengaruh sungkup menyebabkan berbeda tidak nyata terhadap jumlah akar. Media pakis tidak berbeda nyata dengan media sabut kelapa dan kulit pohon akasia namun berbeda nyata dengan perlakuan media arang sekam dan limbah sabut batang aren. Hal ini disebabkan karena kedua jenis media tanaman tersebut merupakan media tanam yang steril, porous dan padat serta dapat menyerap air dengan baik sehingga dapat memicu pertumbuhan akar.

Tabel 9. Analisis statistik pengaruh sungkup dan jenis media tanam terhadap pertambahan jumlah akar

\begin{tabular}{lccc}
\hline \multirow{2}{*}{ Anak Petak } & \multicolumn{2}{c}{ Petak Utama } & \\
\cline { 2 - 3 } & Tanpa & Rata-rata \\
& & Sungkup & \\
\hline Pakis & 0,60 & 1,06 & $0,83 \mathrm{a}$ \\
Sabut kelapa & 0,46 & 1,26 & $0,86 \mathrm{a}$ \\
Arang sekam & 0,80 & 2,00 & $1,40 \mathrm{~b}$ \\
Kulit pohon akasia & 0,66 & 1,56 & $1,11 \mathrm{ab}$ \\
Limbah sabut batang aren & 1,06 & 1,73 & $1,40 \mathrm{~b}$ \\
\hline Rata-rata & 0,72 & 1,52 & \\
& $\mathrm{~A}$ & $\mathrm{~A}$ & \\
\hline
\end{tabular}

Keterangan : Angka yang diikuti oleh huruf kecil yang sama arah vertikal dan huruf besar sama arah horizontal menunjukkan pengaruh tidak berbeda nyata menurut uji jarak berganda Duncan pada taraf nyata $5 \%$. 


\section{Pertambahan panjang akar}

Pertambahan panjang akar berbeda nyata pada berbagai jenis media tanam, sedangkan pengaruh sungkup tidak menyebabkan perbedaan nyata terhadap pertambahan panjang akar (Tabel 10).

Perlakuan media arang sekam berbeda nyata dengan perlakuan media lainnya, sedangkan media pakis, sabut kelapa, kulit pohon akasia dan sabut aren tidak berbeda nyata terhadap panjang akar. Pertambahan panjang akar terbaik terdapat pada jenis media arang sekam. Hal ini disebabkan karena arang sekam memiliki tekstur yang porous, aerasi dan drainase yang baik, memiliki daya serap air dan menyimpan air sehingga akar tumbuh lebih panjang.

Kelembaban udara di sekitar pertanaman walaupun tanpa sugkup sudah cukup memenuhi syarat tumbuh bibit anggrek pada saat aklimatisasi.

Tabel 10. Analisis statistik pengaruh sungkup dan jenis media tanam terhadap pertambahan panjang akar $(\mathrm{cm})$

\begin{tabular}{|c|c|c|c|}
\hline \multirow[b]{2}{*}{ Anak Petak } & \multicolumn{2}{|c|}{ Petak Utama } & \multirow[b]{2}{*}{ Rata-rata } \\
\hline & $\begin{array}{c}\text { Tanpa } \\
\text { sungkup }\end{array}$ & Sungkup & \\
\hline Pakis & 0,58 & 0,77 & $0,68 \mathrm{a}$ \\
\hline Sabut kelapa & 0,71 & 0,62 & $0,66 \mathrm{a}$ \\
\hline Arang sekam & 1,17 & 1,45 & $1,31 \mathrm{~b}$ \\
\hline Kulit pohon akasia & 0,46 & 0,46 & $0,46 \mathrm{a}$ \\
\hline Limbah sabut batang aren & 0,81 & 0,62 & $0,72 \mathrm{a}$ \\
\hline \multirow[t]{2}{*}{ Rata-rata } & 0,75 & 0,78 & \\
\hline & A & $\mathrm{A}$ & \\
\hline
\end{tabular}

Keterangan: Angka yang diikuti oleh huruf kecil yang sama arah vertikal dan huruf besar sama arah horizontal menunjukkan pengaruh tidak berbeda nyata menurut uji jarak berganda Duncan pada taraf nyata 5\%.

\section{Pertambahan bobot brangkasan segar}

Hasil analisis statistik menunjukkan bahwa terjadi pengaruh interaksi antara sungkup dan jenis media tanam terhadap pertambahan bobot brangkasan segar (Tabel 11). Bobot brangkasan segar pada perlakuan media tanam pakis, sabut kelapa, kulit pohon akasia dan limbah sabut aren berbeda tidak nyata antara pemakain sungkup dengan tanpa sungkup, tetapi pada media tanam arang sekam bobot brangkasan segar berbeda nyata pada perlakuan tanpa sungkup dengan sungkup. Bobot brangkasan segar paling tinggi terdapat pada pengaruh interaksi jenis media tanam sekam dengan pemakaian sungkup. Hal ini diduga karena pada proses aklimatisasi membutuhkan kelembaban yang tinggi dan media tanam yang porous sebagai sebagai tempat tumbuh tanaman. Arang sekam merupakan media yang sangat mudah menyerap air namun rendah menyimpan air, sehingga untuk menjaga kelembaban media dibutuhkan sungkup. Pada media tanam arang sekam tanpa sungkup, bibit anggrek yang baru keluar dari botol cenderung cepat kehilangan air karena lapisan lilin belum terbentuk sempurna dan stomata masih membuka setiap saat. Kekurangan air bagi tumbuhan 
dapat menyebabkan aktivitas fisiologis tumbuhan terganggu, sehingga tanaman akan menjadi keriput dan berpengaruh terhadap kesegaran tanaman. Menurut Arfan, dkk (2016) menyatakan bahwa perlakuan sungkup plastik dapat meningkatkan hasil tanaman bawang merah varietas Lembah Palu yang meliputi berat umbi segar per rumpun dan berat umbi segar per 5 rumpun.

Tabel 11. Analisis statistik pengaruh sungkup dan jenis media tanam terhadap pertambahan bobot brangkasan segar (g) pada umur 75 HST

\begin{tabular}{lcc}
\hline & \multicolumn{2}{c}{ Petak Utama } \\
\cline { 2 - 3 } Anak Petak & Tanpa sungkup & Sungkup \\
\hline Pakis & $0,26 \mathrm{a}$ & $0,56 \mathrm{~b}$ \\
Sabut kelapa & $\mathrm{A}$ & $\mathrm{A}$ \\
& $0,21 \mathrm{a}$ & $0,37 \mathrm{ab}$ \\
Arang sekam & $\mathrm{A}$ & $\mathrm{A}$ \\
& $0,27 \mathrm{a}$ & $1,06 \mathrm{c}$ \\
Kulit pohon akasia & $\mathrm{A}$ & $\mathrm{B}$ \\
& $0,10 \mathrm{a}$ & $0,13 \mathrm{a}$ \\
Limbah sabut batang aren & $\mathrm{A}$ & $\mathrm{A}$ \\
& $0,24 \mathrm{a}$ & $0,43 \mathrm{~b}$ \\
\hline
\end{tabular}

Keterangan: Angka yang diikuti oleh huruf kecil yang sama arah vertikal dan huruf besar sama arah horizontal menunjukkan pengaruh tidak berbeda nyata menurut uji jarak berganda Duncan pada taraf nyata $5 \%$.

\section{KESIMPULAN}

Terdapat pengaruh interaksi antara sungkup dan jenis media tanam terhadap pertumbuhan bibit anggrek dendrobium selama aklimatisasi.

Pemakaian sungkup dan jenis media tanam arang sekam menghasilkan luas daun yang paling tinggi $\left(7,44 \mathrm{~cm}^{2}\right)$ dan pertambahan bobot brangkasan segar paling tinggi $(1,06 \mathrm{~g})$.

\section{SARAN}

Pengembangan produksi bibit anggrek dendrobium saat aklimatisasi sebaiknya menggunakan media arang sekam dengan memakai sungkup.

\section{DAFTAR PUSTAKA}

Sumarya, I. Sitepu, P. Sudiartawan. 2007.Perubahan Biosintesis Sukrosa
Sebelum Pertumbuhan Kuncup Ketiak pada Adiputra I G.K., AA. Suardana, I Md Pan (Vanilla planifolia). Laporan hibah bersaing I, Program studi Biologi, Fak MIPA, Universitas Hindu Indonesia, Denpasar.

Andalasari, Tri Dewi, Yafisham, dan Nuraini, 2014. Respon Pertumbuhan Anggrek Dendrobium Terhadap Jenis Media Tanam Dan Pupuk Daun. Fakultas Pertanian Universitas Lampung. Jurnal Penelitian Pertanian Terapan. 14 (1): 76-82.

Arfan Moh., Zainuddin Basri dan Fathurrahman, 2016. Pengaruh Sungkup dan Mulsa terhadap Pertumbuhan dan Hasil Umbi Bawang Merah (Allium ascalonicum L.) Varietas Lembah Palu di Dataran Medium. Agrotekbis 4 (5):500-505 
Astutik.2006. Uji Berbagai Media pada Aklimatisasi Hibrida Dendrobium. Buana Sains.6 (1): 89-92.

Febrizawati, Murniati dan Sri Yoseva, 2014. Pengaruh Komposisi Media Tanam dengan Konsentrasi Pupuk Cair terhadap Pertumbuhan Tanaman Anggrek Dendrobium (Dendrobium sp.). Jom Faperta. 1(2).

Ginting, B., 2008. Membuat media tumbuh anggrek. KP Penelitian Tanaman Hias, Deptan.Dimuat pada surat kabar Sinar Tani, 7 - 13 Mei 2008.

Junaedy A., 2017. Tingkat Keberhasilan Pertumbuhan Tanaman Nusa Indah (Mussaenda frondosa) dengan Penyungkupan dan Lama Perendaman Zat Pengatur Tumbuh Auksin yang Dibudidayakan pada Lingkungan Tumbuh Shading Paranet. Ilmu Pertanian Universitas Al Asyariah. 2 (1): 8-14.

Royani Ken Qusdy dan Erma Prihastanti, 2015. Uji Penggunaan Limbah Sagu sebagai Media Tanam Anggrek (Dendrobium sp.). Buletin Anatomi dan Fisiologi. 23(1): 108-117
Sukmadijaya, D., Diny Dinarti dan Yupi Isnaini. 2013. Pertumbuhan Planlet Kantong Semar (Nepenthes rafflesiana Jack.) pada Beberapa Media Tanam Selama Tahap Aklimatisasi. J. Hort. Indonesia 4(3): 124-130

Surtinah dan Enny Mutryarny, 2013. Frekuensi Pemberian Grow Quick Lb Terhadap Pertumbuhan Bibit Anggrek Dendrobium Pada Stadia Komunitas Pot. Jurnal Ilmiah Pertanian. 10(2): 31-40.

Susanto, dian adijaya, 2018. Agar Dendrobium Rajin Berbunga. Trubus/April 2018 6-11;36-39; 5155.

Wardani S., Hot Setiado, dan Syarifuddin Ilyas, 2013. Pengaruh Media Tanam dan Pupuk Daun terhadap Aklimatisasi Anggrek Dendrobium (Dendrobium sp). Jurnal Ilmu Pertanian Kultivar. 5(1): 11-18.

Widyastoety, D., Nina Solvia dan Muchdar Soedarjo, 2010. Potensi Anggrek Dendrobium dalam Meningkatkan Variasi dan Kualitas Anggrek Bunga Potong. Jurnal Litbang Pertanian, 29(3): 101-106 